UDC 340.12

LBC 67.0

\title{
THE SUPREME COURT OF THE RUSSIAN FEDERATION: THE SUBJECT OF LAW-INTERPRET ACTIVITY OR THE SAME SUBJECT OF INTERPRETATION OF LAW?
}

\author{
Evgeniy M. Terekhov \\ Balakovo Branch of Saratov State Academy of Law, Balakovo, Russian Federation
}

Introduction: in the legal science, the Supreme Court has traditionally been classed as the main subjects of interpretation of law, however, given the recent changes in the legal sphere of society and the peculiarities of the formation of interpretative practice, this approach needs to be investigated. Methods: the methodological basis of this study is a set of methods of scientific knowledge, among which system, analysis and comparative-legal. Results: the author's position based on the work is based on the study of the terms «law-interpret activity» and «interpretation of law», as well as legislation and the results of legal practice on the specifics of the activities of the Supreme Court. Conclusions: as a result of the conducted research, it was established that the priority assignment of the Supreme Court, first of all, to the subjects of the law-interpret activity is more accurate, which is explained by its current status, as well as the degree and level of use of interpretation techniques and technologies in specific areas of public life.

Key words: legal activity, law-interpret activity, interpretative act, interpretation of law, interpretation practice, Supreme Court of the Russian Federation.

УДК 340.12

ББК 67.0

\section{ВЕРХОВНЫЙ СУД РФ: \\ СУБЪЕКТ ПРАВОИНТЕРПРЕТАЦИОННОЙ ДЕЯТЕЛЬНОСТИ ИЛИ СУБЪЕКТ ТОЛКОВАНИЯ ПРАВА?}

\author{
Евгений Михайлович Терехов \\ Балаковский филиал Саратовской государственной юридической академии, \\ г. Балаково, Российская Федерация
}

\begin{abstract}
Введение: в юридической науке Верховный Суд традиционно относят к основным субъектам толкования права, однако с учетом последних изменений в правовой сфере жизни общества и особенностей формирования интерпретационной практики данный подход нуждается в исследовании. Методы: методологическую основу данного исследования составляет совокупность методов научного познания, среди которых системность, анализ и сравнительно-правовой. Результаты: обоснованная в работе авторская позиция опирается на исследование терминов «правоинтерпретационная деятельность» и «толкование права», а также законодательства и результатов юридической практики по вопросу специфики деятельности Верховного Суда. Выводы: в результате проведенного исследования установлено, что более верным представляется приоритетное отнесение Верховного Суда, в первую очередь, к субъектам правоинтерпретационной деятельности, что объясняется его действующим статусом, а также степенью и уровнем использования интерпретационной техники и технологий в конкретных областях общественной жизни.

Ключевые слова: юридическая деятельность, правоинтерпретационная деятельность, интерпретационный акт, толкование права, интерпретационная практика, Верховный Суд РФ.
\end{abstract}




\section{Введение}

В условиях глобализации вслед за усложнением социально-экономической и политической жизни усложняется и правовая жизнь общества. В рамках последней особое место занимает юридическая деятельность, которая в самом общем виде подразделяется на правотворческую, правоинтерпретационную и правоприменительную. Среди всех ее разновидностей правоинтерпретационный вид в отечественной правовой науке исследован меньше других.

Органы судебной власти выступают важнейшими субъектами правоинтерпретационной деятельности. Длительное время среди ученых господствовала точка зрения, согласно которой Верховный Суд является прежде всего субъектом толкования права [1, c. 91]. С учетом принятия нового Федерального конституционного закона в 2014 г. «О Верховном Суде РФ» [11] и специфики его функционирования пришло время проверить актуальность данного мнения.

\section{Анализ элементов}

\section{правоинтерпретационной деятельности и толкования права \\ в работе Верховного Суда РФ}

Для того чтобы относить Верховный Суд к субъектам правоинтерпретационной деятельности или толкования права, стоит понимать: в чем состоит принципиальная разность в данных понятиях; кто является их субъектами; какой юридической силой обладают результаты по раскрытию смысла норм права.

Несмотря на очевидную близость, правоинтерпретационная деятельность и толкование права не представляют собой тождественные понятия.

Правоинтерпретационная деятельность - механизм работы государственно-властных субъектов по раскрытию смысла норм права, реализуемый в определенных рамках (пределах), оканчивающийся изданием интерпретационных актов, вызывающих юридические последствия у субъектов права.

Толкование права - «деятельность органов государства, должностных лиц, общественных организаций, отдельных граждан, направ- ленная на установление содержания норм права, на раскрытие выраженной в них воли социальных сил, стоящих у власти» [6, с. 280].

Субъектами правоинтерпретационной деятельности выступают органы судебной власти РФ (Конституционный Суд РФ и Верховный Суд РФ - ведущие субъекты); органы законодательной власти РФ; органы исполнительной власти РФ. Существенная особенность здесь наличие государственно-властных полномочий у субъектов. В статье 2 Федерального конституционного закона от 05.022014 г. № 3-ФКЗ «О Верховном Суде РФ» [11] закрепляется право Верховного Суда РФ предоставлять официальные разъяснения по вопросам судебной практики, наделяя его полномочиями по координированию процессов толкования права в системе судов общей юрисдикции.

Толкование норм права могут производить абсолютно любые лица без ограничения по субъектам - это могут быть граждане РФ, в том числе и не имеющие юридического образования, различного рода общественные организации и объединения и т. д.

Результаты правоинтерпретационной деятельности имеют юридическую силу и учитываются органами законодательной, исполнительной, судебной власти в работе, а результаты толкования норм права не имеют общеобязательного юридического значения и важны скорее для лица, толкующего норму права.

В постановлении Пленума Верховного Суда РФ от 19 декабря 2003 г. № 23 «О судебном решении» сказано, что «при установлении противоречий между нормами права, подлежащими применению при рассмотрении и разрешении дела, судам также необходимо учитывать разъяснения Пленума Верховного Суда Российской Федерации, данные в постановлениях от 31 октября 1995 г. № 8 «О некоторых вопросах применения судами Конституции Российской Федерации при осуществлении правосудия» и от 10 октября 2003 года № 5 «О применении судами общей юрисдикции общепризнанных принципов и норм международного права и международных договоров Российской Федерации». Суду также следует учитывать постановления Конституционного Суда РФ; постановления Пленума Верховного Суда РФ; постановления Европейского Суда по правам человека [7]. 
Результаты правоинтерпретационной деятельности важны и учитываются при разработке доктринальных документов, к примеру, таких, как проект Концепции правовой политики в РФ. В то же время итоги простого толкования норм права интереса для разработки отмеченных документов не представляют.

Одной из целей правовой политики является формирование и дальнейшее развитие правового государства. Ее достижение предполагает в том числе выявление и расследование преступлений террористической направленности [9, с. 9]. Указанная установка может быть достигнута как при помощи ужесточения законодательства в части назначения наказания за конкретныепреступления террористической направленности [12], так и посредством издания официальных разьяснений, оказывающих воспитательное воздействие на лиц, склонных к совершению преступных деяний. В частности, Пленум Верховного Суда РФ разъяснил, что за вовлечение детей в работу террористических организаций возможно лишение их родителей родительских прав, поскольку такие действия должны расцениваться органами государственной власти как злоупотребление правом на воспитание ребенка [8].

\section{Управление Верховным Судом РФ формированием общей интерпретационной практики}

Если в ходе простого толкования права лишь раскрывается смысл необходимых норм, то в ходе правоинтерпретационной деятельности может происходить управление процессами ее формирования в необходимых для этого объемах, а именно посредством расширения или ограничения толкования. Верховный Суд очень часто прибегает к методам расширительного или ограничительного раскрытия смысла норм права.

Верховным Судом РФ было расширено понятие «угроза» в случае совершения преступления, предусмотренного статьей 119 УК РФ «Угроза убийством или причинением тяжкого вреда здоровью» [10].

Ранее интерпретационная и правоприменительная практика формировались таким образом, что лицо привлекалось к уголовной ответственности за совершение вышеотме- ченного деяния, когда выражало в адрес потерпевшего угрозу причинения смерти либо тяжкого вреда здоровью, а также демонстрировало при этом оружие или предмет, похожий на оружие. Однако Верховный Суд РФ разъяснил, что привлекать к уголовной ответственности за совершение анализируемого преступления можно при отсутствии словесных угроз, когда использование оружия преступником явно свидетельствовало о его желании совершить угрозу убийством или причинением тяжкого вреда здоровью [5].

На территории Иркутской области в одном из кафе произошел конфликт, который закончился применением оружия. Инцидент возник в ходе словесной перепалки между администратором кафе и одним из его посетителей. Последний после выяснения отношений вышел из кафе и вернулся уже с оружием и произвел выстрел в администратора, который от полученных ран скончался на месте. Далее, посетитель направил оружие на брата администратора и других гостей заведения, произведя при этом неоднократные и беспорядочные выстрелы в потолок, не высказывая при этом никаких словесных угроз, после чего покинул заведение. Посетитель с оружием в конечном счете был привлечен к уголовной ответственности за убийство и угрозу убийством. Защита подсудимого пыталась оспорить факт его привлечения за угрозу убийством, однако судебная коллегия по уголовным делам Верховного Суда РФ оставила приговор в силе, указав, что действия подсудимого были квалифицированы по части 1 статьи 119 УК РФ правильно [3].

Таким образом, Верховный Суд РФ расширил понятие «угроза» за совершение угрозы убийства или причинения тяжкого вреда здоровью человека, разъяснив, что для привлечения к уголовной ответственности может и не требоваться факт словесных высказываний в адрес потерпевшего.

В другом случае Верховный Суд РФ, напротив, обратил внимание нижестоящих судов на недопустимость расширительного толкования пункта 5 статьи 28 Закона РФ «О защите прав потребителей» [2] по поводу отношений между банком и вкладчиком в части возврата денежных средств и выплаты неустойки.

Вкладчик обратился в суд с иском к банку о взыскании части вклада, компенсации мораль- 
ного вреда, неустойки, вызванного нарушением сроков возврата суммы вклада, поскольку в связи с расторжением договора банковского вклада денежные средства вкладчику были выплачены частями, а не единой суммой. Суд первой инстанции удовлетворяя заявленные требования частично, взыскал в пользу истца неустойку, компенсацию морального вреда, штраф за несоблюдение в добровольном порядке удовлетворения требований потребителя. Разрешая спор по существу, суд первой инстанции ссылался на пункт 5 статьи 28 Закона РФ «О защите прав потребителей». Суд апелляционной инстанции поддержал в выводах суд первой инстанции, однако увеличил размер сумм взыскания. Верховный Суд РФ указал на ошибочность сформированной интерпретационной практики нижестоящих судов. Сущность заблуждения заключается в том, что за игнорирование банком требований вкладчика о возврате вклада по первому требованию полагается лишь уплата банком процентов по ставке рефинансирования. Более того, закон «О защите прав потребителей», должен применяться к рассматриваемым отношениям лишь в той части, в какой они не урегулированы нормами гражданского законодательства, а гражданское законодательство, к слову, их регулирует достаточно подробно [4].

\section{Выводы}

Таким образом, все более очевидным становится тот факт, что Верховный Суд РФ является все же субъектом правоинтерпретационной деятельности, что следует из анализа законодательства, регулирующего область судебной власти, а также уровня владения интерпретационной техникой и технологией, их использованием в конкретных сферах общественной жизни. Безусловно, в ходе своей работы, высший орган судебной власти осуществляет и толкование норм права, однако более верным представляется приоритетное отнесение Верховного Суда РФ, в первую очередь, к субъектам правоинтерпретационной деятельности.

\section{СПИСОК ЛИТЕРАТУРЫ}

1. Вопленко, Н. Н. Официальное толкование норм права / Н. Н. Вопленко. - М. : Юридическая литература, 1976. -119 с.
2. Закон РФ от 07.021992 г. № 2300-1 «О защите прав потребителей» : (с изм. на 01.05.2017 г.) // Ведомости СНД и ВС РФ. - 1992. - № 15. - Ст. 766.

3. Куликов, В. Взяли на испуг : Верховный Суд расширил понятие угрозы / В. Куликов // Российская газета. - 2017. - 31 авг.

4. Обзор судебной практики Верховного Суда РФ за первый квартал 2017 г. : (утв. Президиумом Верховного Суда РФ 16.022017 г.) // Солидарность. 2017. - 1 марта.

5. Обзор судебной практики Верховного Суда РФ за третий квартал 2017 г. : (угвержден Президиумом Верховного Суда РФ 12.072017 г.) // Солидарность. - 2017. - 19 июля.

6. Общая теория права / под ред. А. С. Пиголкина. - М. : Изд-во МГТУ им. Н. Э. Баумана, 1996. $384 \mathrm{c}$.

7. Постановление Пленума Верховного Суда РФ от 19.122003 г. № 23 «О судебном решении» : (с изм. на 23.062015 г.) // Российская газета. - 2003. 26 дек.

8. Постановление Пленума Верховного Суда РФ от 14.112017 г. № 44 «О практике применения судами законодательства при разрешении споров, связанных с защитой прав и законных интересов ребенка при непосредственной угрозе его жизни или здоровью, а также при ограничении или лишении родительских прав» // Российская газета. 2017. - 20 нояб.

9. Проект Концепции правовой политики в РФ до 2020 г. / под ред. А. В. Малько. - Саратов, 2010. $40 \mathrm{c}$.

10. Уголовный кодекс РФ от 13.06 1996 г. № 63-Ф3 : (с изм. на 29.072017 г.) // Собрание законодательства РФ. $-1996 .-$ № 25. - Ст. 2954.

11. Федеральный конституционный закон от 05.022014 г. № 3-ФКЗ «О Верховном Суде Российской Федерации» : (с изм. на 15.022016 г.) // Российская газета. $-2014 .-7$ февр.

12. Федеральный закон от 06.072016 г. № 375Ф3 «О внесении изменений в Уголовный кодекс РФ и Уголовно-процессуальный кодекс РФ в части установления дополнительных мер противодействия терроризму и обеспечения общественной безопасности» // Российская газета. - 2016. - 11 июля.

\section{REFERENCES}

1. Voplenko N.N. Ofitsialnoe tolkovanie norm prava [Official Interpretation of Legal Norms]. Moscow, Yuridicheskaya literatura Publ., 1976. $119 \mathrm{p}$.

2. Zakon RF ot 07.02.1992 g. № 2300-1 «O zashchite prav potrebiteley»: (s izm. na 01.05.2017 g.) [Law of the Russian Federation of February 7, 1992 no. 2300-1 "On Protection of Consumer Rights" (as 
Amended on May 1, 2017)]. Vedomosti SND i VS RF, 1992, no. 15 , art. 766 .

3. Kulikov V. Vzyali na ispug: Verkhovnyy Sud rasshiril ponyatie ugrozy [Gave a Scare. The Supreme Court Expanded the Concept of Threat]. Rossiyskaya gazeta, 2017, August 31.

4. Obzor sudebnoy praktiki Verkhovnogo Suda RF za pervyy kvartal 2017 g.: (utv. Prezidiumom Verkhovnogo Suda RF 16.022017 g.) [Review of the judicial Practice of the Supreme Court of the Russian Federation for the First Quarter of 2017: (Approved by the Presidium of the Supreme Court of the Russian Federation on February 16, 2017)]. Solidarnost, 2017, March 1.

5. Obzor sudebnoy praktiki Verkhovnogo Suda RF za tretiy kvartal 2017 g.: (utverzhden Prezidiumom Verkhovnogo Suda RF 12.07 2017 g.) [Review of the Judicial Practice of the Supreme Court of the Russian Federation for the Third Quarter of 2017: (Approved by the Presidium of the Supreme Court of the Russian Federation on July 12, 2017)]. Solidarnost, 2017, July 19.

6. Pigolkin A.S., ed. Obshchaya teoriya prava [The General Theory of Law]. Moscow, Izd-vo MGTU im. N. E. Baumana, 1996. 384 p.

7. Postanovlenie Plenuma Verkhovnogo Suda RF ot 19.122003 g. № 23 «O sudebnom reshenii»: (s izm. na 23.062015 g.) [Resolution of the Plenum of the Supreme Court of the Russian Federation of December 19, 2003 no. 23 "On the Judicial Decision" (as Amended on June 23, 2015)]. Rossiyskaya gazeta, 2003, December 26.

8. Postanovlenie Plenuma Verkhovnogo Suda RF ot 14.112017 g. № 44 «O praktike primeneniya sudami zakonodatelstva pri razreshenii sporov, svyazannykh s zashchitoy prav i zakonnykh interesov rebenka pri neposredstvennoy ugroze ego zhizni ili zdorovyu, a takzhe pri ogranichenii ili lishenii roditelskikh prav»» [Decision of the Plenum of the Supreme Court of the Russian Federation of November 14, 2017 no. 44 "On the Practice of Application by Courts the Legislation in Resolving Disputes Related to the Protection of the Rights and Legitimate Interests of the Child in the Immediate Threat of Their Life or Health, as Well as Limiting or Depriving Parental Rights"]. Rossiyskaya gazeta, 2017, November 20.

9. Malko A.V., ed. Proekt Kontseptsii pravovoy politiki $v$ RF do $2020 \mathrm{~g}$. [Draft Conception of Legal Policy in the Russian Federation until 2020]. Saratov, $2010.40 \mathrm{p}$.

10. Ugolovnyy kodeks RF ot 13.061996 g. № 63-FZ: (s izm. na 29.072017 g.) [The Criminal Code of the Russian Federation of June 13, 1996 no. 63-FL (as Amended on July 29, 2017)]. Sobranie zakonodatelstva RF [Collected Legislation of the Russian Federation], 1996, no. 25, art. 2954.

11. Federalnyy konstitutsionnyy zakon ot 05.02 2014 g. № 3-FKZ «O Verkhovnom Sude Rossiyskoy Federatsii»: (s izm. na 15.022016 g.) [Federal Constitutional Law of February 5, 2014 no. 3-FKL "On the Supreme Court of the Russian Federation" (as Amended on February 15, 2016)]. Rossiyskaya gazeta, 2014, February 7.

12. Federalnyy zakon ot 06.072016 g. № $375-\mathrm{FZ}$ «O vnesenii izmeneniy v Ugolovnyy kodeks RF i Ugolovno-protsessualnyy kodeks RF v chasti ustanovleniya dopolnitelnykh mer protivodeystviya terrorizmu i obespecheniya obshchestvennoy bezopasnosti» [Federal Law of July 6, 2016 no. 375-FL "On Amendments to the Criminal Code of the Russian Federation and the Criminal Procedure Code of the Russian Federation with Regard to the Adoption of Additional Measures to Counter Terrorism and Ensure Public Safety"'. Rossiyskaya gazeta, 2016, July 11.

\section{Information about the Author}

Evgeniy M. Terekhov, Candidate of Juridical Sciences, Associate Professor, Department of State and Legal Disciplines, Balakovo Branch of Saratov State Academy of Law, Krasnaya Zvezda St., 8/1,413865 Balakovo, Russian Federation, terehov1989@yandex.ru.

\section{Информация об авторе}

Евгений Михайлович Терехов, кандидат юридических наук, доцент кафедры государственно-правовых дисциплин, Балаковский филиал Саратовской государственной юридической академии, ул. Красная Звезда, 8/1, 413865 г. Балаково, Российская Федерация, terehov1989@yandex.ru. 